McFadzean et al. (1953), who successfully treated 14 cases by this method.

\section{Summary}

Pylephlebitis and solitary liver abscess are both sequels to intra-abdominal infection.

The incidence of pylephlebitis after appendicitis was much less in the past 10 years than in the years 1930-40. The incidence of pylephlebitis and solitary liver abscess due to other causes is not reduced to the same extent.

The outlook is very much better for cases treated in the past 10 years than for cases treated in 1930-40.

A clinical diagnosis can be made by recognizing a pattern of clinical features and laboratory findings.

Laparotomy findings or histopathological evidence is required for confirmation of the diagnosis.

Treatment is by elimination of any known intra-abdominal infection, administration of an adequate course of antibiotics, and drainage of intrahepatic abscesses if present.

There is a tendency for rclapse to occur when treatment is discontinued, and laboratory tests are of assistance in judging the progress of the case and in deciding when antibiotics should be discontinued.
I would like to thank the surgeons of the London Hospital and St. Margaret's Hospital, Epping, for permission to publish details of cases admitted under their care; Mr. E. C. B. Butler for his encouragement and help in the preparation of this paper; and Professor Doniach and Dr. K. Weinbren, of the Bernhard Baron Institute of Pathology, for their help in the interpretation of the histology of these cases.

\section{RBFERENCES}

Beaver, D. C. (1931). Amer. 9. Path., 7, 259.

Bryant, J. H. (1897). Guy's Hosp. Rep., $54,77$.

Colp, R. (1926). Surg. Gynec. Obstet., 43, 627.

Cronin, K. (1961). Gut, 2, 53.

D'Abreu, F. (1946). Proc. roy. Soc. Med., 39, 309

Eliason, E. L. (1926). Surg. Gynec. Obstet., $42,510$.

Gamm, K. E. (1945). \%. Amer. med. Ass., 128, 1159.

Harley, H. R. S. (1955). Ann. roy. Coll. Surg. Engl., 17, 201.

Hawkes, S. Z. (1938). Surg. Gynec. Obstet., 66, 62.

Klinefelter, H. F., Grose, W. E., and Crawford, H. J. (1960). Bull. fohns Hopk. Hosp., 106, 65.

McFadzean, A. J. S., Chang, K. P. S., and Wong, C. C. (1953). Brit. \$. Surg., 41, 141.

Ochsner, A., DeBakey, M., and Murray, S. (1938). Amer. f. Surg., 40, 292.

Ottenberg, R., and Berck, M. (1938). F. Amer. med. Ass., 111, 1374.

Pancoast, H. K. (1926). Amer. F. Roentgenol., 16, 303.

Rothenberg, R. E., and Linder, W. (1934). Surg. Gynec. Obstet., 59, 31. Shaldon, C. (1958). Brit. 7. Surg., 45, 357.

Stokes, J. F. (1960). Lancet, 1, 355.

Wtokes, J. F. (1960). Lancet, 1, 355. Med., 45, 2082.

Wishart, J. H., and Peterson, L. J. (1947). F. Amer. med. Ass., 133, 539.

\title{
Use of 6-Phosphogluconate Dehydrogenase as a Screen Test for Cervical Carcinoma in Normal Women
}

\author{
G. G. MUIR,* M.B., в.S., M.SC. ; G. CANTI, † M.B., B.S., M.C.PATH ; D. WILLIAMS, $\ddagger$ M.B., B.S., F.R.C.S., M.R.C.o.G.
}

The remarkable achievements of exfoliative cytology in the early diagnosis of occult carcinoma of the cervix have shown that it is desirable to screen all women over 30 . Unfortunately, such a large survey would overwhelm our cytological services, which are limited by the shortage of cytologists and technicians. For this reason attempts have been made to employ some of the basic biochemical properties of the malignant cell in diagnostic tests.

Odell and Burt (1950) and Fishman et al. (1950) reported their experiences in the use of beta-glucuronidase as a diagnostic test for carcinoma of the cervix. In both series it was found that with carcinoma there was likely to be a higher level of betaglucuronidase in the vaginal fluid than in normal women. In post-menopausal women the distinction was not so clear. Lawson (1959) obtained similar results in this country but found not only an overlap of enzyme values in benign and malignant conditions but also low levels in certain cases of carcinoma of the cervix. Hatzimichael (1962) studied the content of beta-glucuronidase in the cervical mucous plug, as distinct from vaginal fluid, and found in general a marked difference between benign and malignant conditions. $\mathrm{He}$ also found that carcinoma of the cervix was very seldom associated with low levels of beta-glucuronidase in cervical mucus.

Beta-glucuronidase, from the length of estimation and its biochemical properties, has certain disadvantages as a screening test (Walker, 1952 ; Walker and Levvy, 1952, 1953 ; de Duve et al., 1955 ; Watkins and Lawson, 1963).

- Assistant Chemical Pathologist, St. Bartholomew's Hospital, London. † Cytologist. St. Bartholomew's Hospital, London.

¥ Resident Assistant Obstetric and Gynaecological Surgeon, St. Bartholomew's Hospital, London.
Bonham and Gibbs (1962) estimated the 6-phosphogluconate dehydrogenase content of the high vaginal fluid in a number of selected benign and malignant gynaecological conditions. In their series the enzyme levels gave a definite distinction between benign and malignant disease, there being only three benign conditions with high levels of enzyme and no cases of carcinoma with low levels.

Both histochemically and biochemically 6-phosphogluconate dehydrogenase has been shown to be increased in benign and malignant hyperplasias (Chayen, 1961 ; Kotnis et al., 1962a, 1962b ; Scott et al., 1962). 6-Phosphogluconate dehydrogenase is a cytoplasmic enzyme which facilitates its release from the cellular debris of the vaginal fluid. As the enzyme is linked to nicotine adenine dinucleotide phosphate, changes in ultraviolet absorption give a simple and rapid means of estimation.

A "well women's diagnostic clinic" has been established in the gynaecological department of this hospital in conjunction with the Corporation of the City of London. Here women are screened for carcinoma of the cervix by means of pelvic examination and exfoliative vaginal and cervical cytology. Such a clinic provides ideal material for the evaluation of the enzyme assay as a screening test, and this paper reports our preliminary findings.

\section{Methods}

The samples were obtained in a manner similar to that described by Bonham and Gibbs (1962). The enzyme assay was essentially that of Glock and McLean (1953) modified by Bonham and Gibbs (1962). Following these authors an enzyme 
level of more than 100 units/g. dry weight was taken to be suggestive of malignant disease.

Cytology was carried out and graded by Papanicolaou's (1954) technique. Patients whose cervical smears showed cells of Classes IV-V were admitted and either a cone biopsy or a total hysterectomy was carried out. The cervix was fixed and where practical cut radially into 12 segments ; standard paraffin sections were stained with haematoxylin and eosin.

The cytological smears were also inspected for the presence of inflammatory changes, organisms, and erythrocytes.

\section{Results}

Table I shows the overall results. Of the 190 patients examined, 36 had enzyme levels greater than 100 units, but in 35 of these there was no cytological evidence of malignancy. (Three cases with class III smears were negative on further investigation.) However, this small group of 190 patients yielded three cases with positive smears, and two of these, which histologically were found to have carcinoma-in-situ (one with early invasion), had complete absence of 6-phosphogluconate dehydrogenase even with repeated tests. A third case was found to have a carcinoma-in-situ with early invasion; in this case, however, the enzyme level was 190 units.

\begin{tabular}{c|c|c}
\multicolumn{2}{c}{ TABLE I.-Cytology } \\
\hline Enzyme Level & Classes I, II, III & Classes IV, V \\
\hline $\begin{array}{c}100 \text { units/g. } \\
\geqslant 100 \text { units/g. }\end{array}$ & $\begin{aligned} 152 \\
35\end{aligned}$ & 2 \\
\hline
\end{tabular}

The patients with raised enzyme levels without proved carcinoma were analysed as shown in Table II ; they seemed to fall into four groups: (1) those menstruating at the time of the test, (2) pre-menopausal patients with some gynaecological or cytological abnormality, (3) post-menopausal patients, and (4) those with no obvious explanation. Five out of seven patients in whom the test was made during menstruation had more than 100 units; the other two were tested on the last day of the period.

TABLE II

\begin{tabular}{|c|c|c|c|}
\hline & \multirow{2}{*}{$\begin{array}{l}\text { Total } \\
\text { No. }\end{array}$} & \multicolumn{2}{|c|}{$\begin{array}{l}\text { Enzyme Level in } \\
\text { Units/g. Dry Weigh }\end{array}$} \\
\hline & & $\begin{array}{l}\geq 100 \\
\text { Units }\end{array}$ & $\begin{array}{l}<100 \\
\text { Units }\end{array}$ \\
\hline 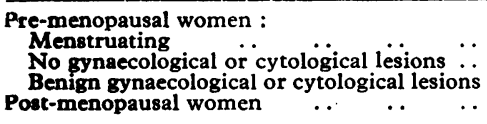 & $\begin{array}{r}7 \\
95 \\
57 \\
28\end{array}$ & $\begin{array}{r}5 \\
4 \\
15 \\
11\end{array}$ & $\begin{array}{l}2 \\
91 \\
42 \\
17\end{array}$ \\
\hline
\end{tabular}

In the pre-menopausal group (excluding those with positive smears and the menstruation cases) 19 (12.5\%) out of $152 \mathrm{had}$ raised enzyme levels ; of the 95 with no gynaecological or cytological disease, 71 had values under 20 units. There were, however, two with over 80 units-the upper limit for normal women suggested by Bonham (1964) -and four with over 100 units, for which there was no gynaecological or cytological explanation. Of the 57 with gynaecological or cytological abnormality other than carcinoma, 15 had enzyme concentration greater than 100 units $/ g$. dry weight. The 15 with raised enzyme levels all had blood or pus cells in the smears. The lesions encountered were: erosions and polyps 6 , non-specific inflammation 4, Trichomonas vaginalis infection 2 , fibroids 2 , endometriosis 1 (trichomonas vaginitis gave the highest levels -one as high as 14,000 units); the other 42 cases with low enzyme levels included erosions and polyps 21 , cervicitis 6 , fibroids 11, cervical leucoplakia 1.

There was a higher incidence-11 (39\%) out of $28-$ of raised enzyme levels in the post-menopausal group. In these cases the cytological picture was generally that of a basal-cell hyperplasia, often with large numbers of stripped nuclei ; some had, in addition, evidence of infection, and in the two cases in which Trichomonas vaginalis was demonstrated the enzyme levels were again exceptionally high.

\section{Discussion}

Excluding the menstruating patients, our figures show that 30 $(16 \%)$ of the "well women" attending the clinic gave a "positive" result (more than 100 units/g. dry weight) with the 6-phosphogluconate dehydrogenase test in the absence of any clinical or cytological evidence of malignancy. In four of these there was no evidence of disease to account for the raised enzyme levels, a finding which is as yet unexplained.

The 15 pre-menopausal patients with clinical abnormalities, in whom raised enzyme levels were found, all had cytological evidence of inflammation. In a histochemical study, Smith and Rubinstein (1962) showed that the nicotine-adeninedinucleotide-phosphate-linked enzymes, of which 6-phosphogluconate dehydrogenase is one, are all present in high concentration in cells of an inflammatory exudate in the central nervous system. The presence of such exudate could explain the raised levels in these cases. Similarly, the high 'erythrocyte concentration of 6-phosphogluconate dehydrogenase content in erythrocytes affords a reasonable explanation of the high levels associated with menstruation in the present investigation.

The high incidence of raised levels in the samples from postmenopausal women recalls the similar findings with betaglucuronidase obtained by Lawson (1959). The cytological picture was similar in all cases-that is, a marked basal-cell hyperplasia associated with sheets of stripped nuclei. The demonstration by Chayen (1961) and Scott et al. (1962) that 6-phosphogluconate dehydrogenase is increased in cellular hyperplasia, whether benign or premalignant, is a convincing explanation of the high enzyme levels found in association with this type of smear.

That two cases of carcinoma-in-situ were not detected is a disquieting result. In both, repeated analysis failed to show any sign of elevation of the enzyme level. In the one case in which the enzyme level was raised histology showed early stromal invasion, but one of the cases without any increase in enzyme showed similar early invasion. An elevated enzyme level appears to require the presence of inflammatory cells, erythrocytes, basal hyperplasia, or malignant cells in the vaginal fluid. In a separate, and as yet unpublished, series of cases of invasive carcinoma all had raised enzyme levels, though these have varied considerably on repeated sampling. Possibly the failure to obtain activity greater than 100 units/g. dry weight of vaginal fluid in the two cases of early cervical carcinoma may be due to inadequate release of the enzyme, such as occurs with beta-glucuronidase. There must be considerable dilution of the cells shed from carcinoma-in-situ, and small growth may sometimes yield specimens of vaginal fluid free of such cells ; fluctuation in the number of cells sampled might explain the variation in the enzyme levels that we have found in cases of established carcinoma. This problem is not solved by reconstituting to a constant weight/volume ratio, owing to variation in the other constituents of high vaginal fluid, such as mucus and electrolytes.

This investigation has been confined to the evaluation of 6-phosphogluconate dehydrogenase as a screening test for carcinoma of the cervix, because it is only in this region that cytology is accurate enough for control purposes. It should be mentioned, however, that a number of cases of malignant disease in other parts of the female genital tract, not included in the present investigation, have yielded raised enzyme levels in the vaginal fluid in the absence of cytological evidence of malignancy. The test would therefore appear to have some value in gynaecology, but the high incidence of raised enzyme concen- 
trations in benign conditions is a disadvantage. However, the failure to detect two out of three early carcinomas of the cervix precludes its use as a screening test in its present form.

\section{Summary}

Experience with assays of 6-phosphogluconate dehydrogenase in vaginal fluid as a screen test for cervical carcinoma in parallel with cervical cytology is described. Among the 190 cases studied, three cases of carcinoma-in-situ were found. Two of the three carcinomas-in-situ did not have raised enzyme levels. Thirty-five patients had raised enzyme levels without carcinoma. The causes of high enzyme concentration in the absence of carcinoma and low concentration in carcinoma-in-situ as distinct from frank carcinoma are discussed.

We wish to acknowledge the funds presented to us by the Common Council of the City of London and the British Empire Cancer Campaign. This work was carried out while one of us (G. G. M.) held the Gillson Scholarship in Pathology of the Worshipful Society of Apothecaries of London. We are grateful to Mr. J. Beattie and the surgeons of the gynaecology department for access to patients under their care, and to Professor W. G. Spector and Dr. A. B. Anderson for advice and encouragement.

REFERENCES

Bonham, D. G. (1964). Triangle, 6, 157.

- and Gibbs, D. F. (1962). Brit. med. 7., 2, 823.

Chayen, J. (1961). Ann. Rep. roy. Coll. Surg. Engl., 68, 75.

de Duve, C., Pressman, B. C., Gianetto, R., Wattiaux, R., and AppelDuve, C., Pressman, B. C., Gianetto, $R$,

Fishman, W. H., Kasdon, S. C., and Homburger, F. (1950). 9. Amer. med. Ass., 143, 350 .

Glock, G. E., and McLean, P. (1953). Biochem. 7., 55, 400.

Hatzimichael, A. (1962). Amer. Ұ. Obstet. Gynec., 84, 94.

Kotnis, L. B., Narurkar, M. V., and Sahasrabudhe, M. E. (1962a). Brit. f. Cancer, 16, 541 .

- (1962b). Ibid., 16, 550.

Lawson, J. G. (1959). 尹. Obstet. Gynaec. Brit. Emp., 66, 946.

Odell, L. D., and Burt, J. C. (1950). F. Amer. med. Ass., 142, 226.

Papanicolaou, G. N. (1954). Atlas of Exfoliative Cytology. Oxford, London.

Scott, D. B. M., Morris, A. L., Reiskin, A. B., and Pakoskey, A. M (1962). Cancer Res., 22, 857.

Smith, B., and Rubinstein, L. J. (1962). F. Path. Bact., 83, 572.

Walker, P. G. (1952). Biochem. F., 51, 223.

and Levvy, G. A. (1952). İbid., 51, 20.

Wa (1953). Ibid., 54, 56.

Watkins, D. K., and Lawson, J. G. (1963). Clin. Chim. Acta, 8, 646.

\title{
Control of Tuberculosis in Pakistani Immigrants
}

\author{
W. EDGAR,* M.B., CH.B., D.P.H., D.C.H.
}

There has been a small community of Pakistanis in Bradford for some years, but towards the end of 1960, possibly owing to the impending restrictions on entry into this country, the number rose at an alarming rate. At the 1961 Census there were 4,969 Indians and Pakistanis, and by the end of 1963 it is estimated that the number of coloured immigrants had increased to 12,688 , of whom $10,863(85.6 \%)$ were Pakistanis.

The reason for their presence here is that the local textile trade provides many suitable jobs for them. The largest proportion are employed in the mills, particularly in simple unskilled jobs like woolcombing and the ancillary textile processes, where the atmosphere tends to be hot and humid. In many mills the night shift is composed almost entirely of Pakistanis. Apart from administrative and clerical staff, $20 \%$ of the male textile force are coloured. Others are engaged in foundry work, in public transport, and in unskilled engineering. The great majority are men aged 20 to 40 whose length of stay is limited to a few years, during which time they support their wives and families by sending money home to Pakistan. Those who have set up in business along with those who have brought their families with them are likely to remain permanently, and although the number is not great it is steadily increasing.

The number of newly arrived Commonwealth immigrants who registered at the Bradford Employment Exchange between 1959 and 1963 is shown in Table I. These are almost entirely from Pakistan. Undoubtedly others, of whom the Exchange would have no record, obtained jobs within a few days of arrival, although the number is probably small. Those who entered the country with a voucher for employment with a specific employer would proceed direct to their job, and would not register at the Employment Exchange. Approximately 83 such vouchers were issued during 1963 in respect of Pakistanis and Indians coming to employment in Bradford. These figures * Formerly Deputy Medical Officer of Health and Deputy Principal
School Medical Officer, City of Bradford. relate to new arrivals in the United Kingdom and do not include those moving into Bradford from other parts of the country.

I am indebted to Miss M. Gething, Manager of the Employment Exchange, for the following account, on 20 December 1963, of the effect of the Commonwealth Immigrants Act.

"The main object of the Commonwealth Immigrants Act 1962 is to control immigration of Commonwealth citizens to the United Kingdom. The basic feature of this control is that all Commonwealth citizens to whom the Act applies and who wish to enter Great Britain for the purpose of taking or seeking employment must obtain a voucher from the Ministry of Labour. These vouchers are issued to three categories of Commonwealth citizens: (a) those to whom an employer in Great Britain is prepared to make a genuine offer of employment ; $(b)$ those with certain special qualifications or skill but with no job to come to; and $(c)$ those not included in category $a$ or $b$.

"Vouchers are issued without restriction to persons coming within categories $a$ and $b$, but the number issued in category $c$ is controlled. The Government's policy is to control the flow of immigrants into the country so that they do not come here faster than they can be absorbed into our national life.

TABLE I.-New Arrivals of Commonwealth Immigrants Attending the

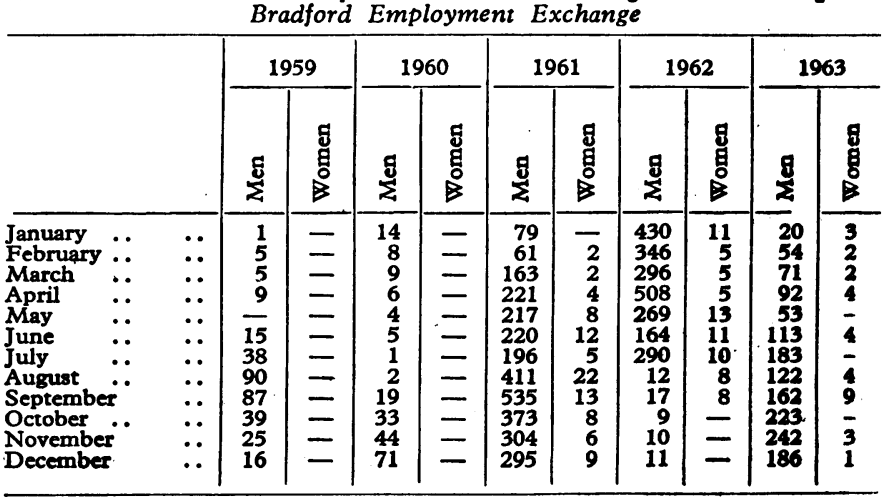

